\section{India's troubled space plans receive unexpected French boost}

New Delhi \& Paris

FRANCE last week signed bilateral agree ments with India in the life sciences and agreed to help with India's troubled rocket programme and to strengthen nuclear ties between the two countries. The agreement on nuclear power would permit the French company Framatome to build two 900-MW light-water nuclear reactors in India provided that India agreed to use them for peaceful purposes only.

In the space arena, France has offered assistance for India's launch vehicle programme, which has been lagging after two successive mishaps. Hubert Curien, France's minister for research and technology, says immediate assistance can be given on the technology for clustering rocket engines, but a request for help with cryogenic motors may be delayed because of its commercial implications.

Curien says France could still provide this technology in consultation with its European partners if India agreed not to put the technology to military use and avoid any future competition with Arianespace in the international launch business.

According to the terms of the life sciences agreement, a joint venture company will produce six different vaccines using the technology supplied by Institut Marieux, which will hold 25 per cent of the company's share capital. The vaccine plant, to be built at Gurgaon near

New Delhi, will start commercial production in 1991.

Defence cooperation was not on Mitterrand's agenda because the subject had already been discussed during the visit of the French defence minister in December 1988. France is said to have offered a $\$ 2,000$ million package for collaboration that includes a contract for the design of India's third aircraft carrier, the supply of an advanced jet trainer, air-toair missiles and anti-tank helicopters. Avions Marcel Dassault of France has been hired as a design consultant for the light combat aircraft India is building.

The French cultural festival in India that prompted Mitterrand's visit had a marked edge of high technology, as was evident from the inaugural show - a spectacular extravaganza in Bombay's Chowpathy Bay. Thousands of Indians, in the company of Mitterrand and Prime Minister Rajiv Gandhi, watched the bay reverberate to amplified music, with giant water screens providing the backdrop for eerie images - fusions of art and science drawn by computer-controlled laser beams reflected from huge mirrors atop barges amid a massive display of pyrotechnics that set the night on fire. According to a French diplomat, the effort was worth it if it had helped to impress on Indians that France can offer something more than wine and cheese.

K.S. Jayaraman \& Peter Coles

\title{
First report on US AIDS behaviour
}

\section{Washington}

THE first report* solely to address the behavioural aspects of the AIDS epidemic was released last week by a committee of social scientists organized by the US National Academy of Sciences. The committee decried the dearth of information available on sexual behaviour and intravenous drug abuse, and called for more studies to find viable ways of changing people's behaviour to lower their risk of infection with HIV, the virus causing AIDS.

The committee's report is the fourth major analysis of the AIDS problem to be conducted in the United States. The Academy and the Institute of Medicine teamed up in 1986 and again last year to offer their assessment of how to counter the epidemic, and the presidential commission on the HIV epidemic issued a laundry list of about $\mathbf{5 7 5}$ specific recommendations last year. Although some of the recommendations in these reports have been implemented, more controversial steps such as anti-discrimination legislation and random blood testing for HIV antibodies have been snarled in political battles.

The Academy committee recommends more systematic studies of human sexual practices and drug abuse patterns. Committee chairman Lincoln E. Moses from Standford University says "AIDS is a social disease", and that not enough effort has so far been put into studying the behaviours that put people at risk and learning how best to motivate them to change. The committee also recommended anonymous blood testing of all newborns.

Marshall H. Becker, from the School of Public Health of the University of Michigan, says the "Just Say No" approach favoured by the Reagan Administration is not working, and that more practical approaches for reducing risk must be used. Among the committee's recommendations for encouraging behaviour changes are expanded sex education for teenagers, condom advertising on television, and free distribution of needles to drug addicts until they enter treatment programmes.

\section{Japan prize awards}

THIS year's Japan prize has been awarded to two US chemists working in different fields. The $¥ 50$ million $(\$ 400,000)$ awards will go to F. Sherwood Rowland, an atmospheric chemist at the University of California at Irvine, and to Elias James
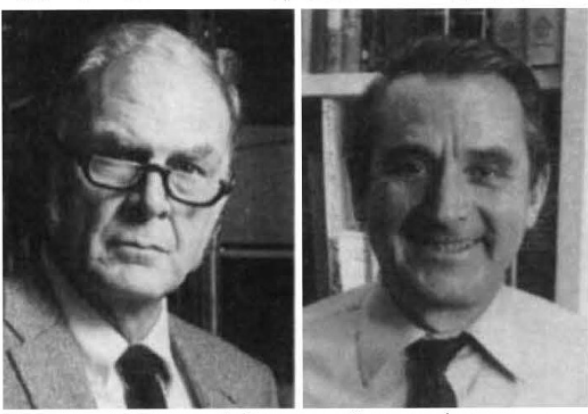

Rowland (left) and Corey - Japan winners.

Corey, an organic chemist at Harvard University. They will be presented on 12 April in Tokyo.

Rowland is recognized for establishing that chlorofluorocarbons (CFCs) can destroy ozone in the stratosphere (see Nature 249,$810 ; 1974)$. He predicted that if CFCs were to continue to be released into the atmosphere at 1974 rates, there would be a 7-13 per cent depletion of total ozone. Corey's award is for his contributions to the synthesis of prostaglandins.

The Japan prize is awarded each year in two predetermined categories. This year's categories were medicinal science and environmental science and technology. Next year's will be for the technology of integration and for Earth sciences. J.P. Peking man safe?

THE municipal government of Beijing (Peking) has introduced regulations to protect the site, now in the suburbs of the city, where the remains of Peking man were found. Under the new regulations all activities are prohibited that may destroy the land-form, terrain and ecological environment, including mining, tree-felling, hunting and the construction of factories that could be a source of pollution. Illegal excavation or selling or buying fossils and remains are also prohibited.

\section{EMBL déjà vu}

LENNART Philipson, director of the European Molecular Biology Laboratory in Heidelberg, will continue in his post until 1995 rather than leave next year as originally intended.

Faced with the withdrawal of the only candidate to replace Philipson (see Nature 337, 397; 2 February 1989), the laboratory's council last week decided to extend Philipson's stay. His original appointment was from 1982 to 1987 , which was then extended for only three years. As a condition of continuing in post beyond 1990 Philipson successfully insisted on a fiveyear reappointment. 